\title{
Strategi Pembangunan Pertanian Berkelanjutan Di Pedesaan Berbasis Citra Drone (Studi Kasus Desa Sukadamai Kabupaten Bogor)
}

\author{
Ihsan Arham¹, Sofyan Sjaf², dan Dudung Darusman³
}

1Program Studi Ilmu Pengelolaan Sumberdaya Alam dan Lingkungan, Sekolah Pascasarjana, Institut
Pertanian Bogor; e-mail: ihsanarham84@gmail.com
2Departemen Sains Komunikasi dan Pengembangan Masyarakat, Fakultas Ekologi Manusia, Institut
PertanianBogor; e-mail: sofyansjaf@apps.ipb.ac.id
3Departemen Manajemen Hutan, Fakultas Kehutanan, Institut PertanianBogor; e-mail: dudungdarusman@gmail.com

\begin{abstract}
ABSTRAK
Sebagian besar aktifitas sektor pertanian berada di pedesaan, sehingga pembangunan pertanian dan desa dapat berjalan secara bersamaan.Pembangunan pedesaan dan pertanian membutuhkan informasi spasial secara akurat agar ketepatan dalam perencanaan pembangunan berkelanjutan dapat tercapai.Penelitian ini bertujuan untuk mengetahui penggunaan lahan aktual, daya dukung lahan pertanian, dan mengkaji arahan perencanaan pembangunan pertanian berkelanjutan di Desa Sukadamai.Metode penelitian ini menggunakan pendekatan data spasial berupa citra desa yang diperoleh dari inovasi teknologi drone. Analisis penggunaan lahan aktual menggunakan perangkat lunak Arcgis melalui proses digitasi secara partisipatif. Analisis daya dukung lahan pertanian dengan menggunakan pendekatan ketersediaan lahan dan kebutuhan lahan.Hasil analisis tersebut menjadi rujukan untuk mengkaji arahan perencanaan pembangunan desa pertanian berkelanjutan di Desa Sukadamai.Analisis prioritas alternatif program menggunakan pendekatan Analytical Hierarchy Process (AHP).Hasil penelitian menemukan bahwa daerah pertanian mendominasi penggunaan lahan di Desa Sukadamai seluas 112.942 ha (42.693 \%).Daya dukung lahan di Desa Sukadamai dalam keadaan defisit atau melampaui daya dukungnya dengan rasio perbandingan ketersediaan lahan (SL) terhadap kebutuhan lahan (DL) sebesar 0.22.Strategi yang menjadi prioritas utama dalam mewujudkan pembangunan pertanian berkelanjutan di Desa Sukadamai adalah penerapan inovasi intensifikasi lahan yang efektif dan efisien (0.215).Kriteria yang menjadi prioritas utama adalah adil secara sosial (0.384).Aktor prioritas utama dalam mewujudkan tujuan pembangunan adalah pemerintah $(0.431)$.
\end{abstract}

Kata kunci: Perencanaan spasial, pedesaan, pertanian berkelanjutan, daya dukung lahan, AHP.

\begin{abstract}
Most agricultural sector activities are in rural areas, so that agricultural and village development can go hand in hand. Rural and agricultural development requires accurate spatial information so that accuracy in sustainable development planning can be achieved. This study was aimed to determine the existing land use, carrying capacity of agricultural land, and analyze the direction of sustainable agriculture development planning in Sukadamai Village. This research method uses a spatial data approach in the form of village images obtained from drone technological innovation. Analysis of existing land use using Arcgis software through a participatory digitization process. Analysis of the carrying capacity of agricultural land using the approach of land availability and land requirements. The results of the analysis become a reference for reviewing the strategy of sustainable agriculture village development planning in Sukadamai Village. Analysis of alternative program priorities using the Analytical Hierarchy Process (AHP) approach. The results found that agricultural areas dominated 112,942 ha of land use in Sukadamai Village $(42,693 \%)$. The carrying capacity of land in Sukadamai Village is in a deficit state or exceeds its carrying capacity with a ratio of land availability (SL) to land needs (DL) of 0.22 . The strategy that becomes the main priority in realizing sustainable agricultural development in Sukadamai Village is the application of effective and efficient land intensification innovations $(0.215)$. The criterion that becomes the first priority is socially just (0.384). The main priority actor in realizing development goals is the government (0.431).
\end{abstract}

Keywords: Spatial planning, rural, sustainable agriculture, land carrying capacity, AHP

Citation: Arham, I., Sjaf, S., dan Darusman, D. (2019). Strategi Pembangunan Pertanian Berkelanjutan di Pedesaan Berbasis Citra Drone (Studi Kasus Desa Sukadamai Kabupaten Bogor). Jurnal Ilmu Lingkungan, 17(2),245-255, doi:10.14710/jil.17.2.245-255 


\section{Latar Belakang}

Pemerintah Republik Indonesia telah menerapkan berbagai kebijakan peningkatan produktivitas pertanian dan kesejehteraan petani. Faktanya hasil sensus pertanian 2013 menemukan bahwa jumlah rumah tangga usaha pertanian di Indonesia mengalami penurunan sebesar 16.32 persen selama rentang waktu 2003-2013. Rumah tangga usaha pertanian pada tahun 2003 sebanyak 31.23 juta keluarga menurun menjadi 26.14 juta pada tahun 2013 (BPS 2013). Hal tersebut mengindikasikan bahwa sektor pertanian ditinggalkan oleh keluarga petani di Indonesia khususnya generasi muda. Susilowati (2016) mengungkapkan faktor-faktor yang memengaruhi berkurangnya minat pekerja muda ke sektor pertanian adalah: 1) sektor pertanian dinilai kurang bergengsi, memiliki risiko tinggi, kurangnya stabilitas dan keberlanjutan pendapatan; 2) luas lahan yang dikuasai semakin menyempit, keragaman usaha dan industri baik di sektor pertanian maupun non pertanian tidak berkembang di desa; 3) pengelolaan usaha tani banyak yang mengalami kegagalan; 4) kurangnya dukungan kebijakan terhadap petani muda atau petani pemula; dan 5) trend cara pandang di kalangan pemuda dalam era postmodern.

Salah satu peluang dalam mengembangkan pertanian nasional adalah dengan memulai dari desa sebagai tingkat hirarki pemerintahan yang sangat dekat dengan masyarakat.Selain itu, pengembangan usaha tani on-farm lebih banyak berkembang di kalangan masyarakat desa.Sjaf (2017) mengemukakan bahwa dari 74,754 desa di Indonesia, 73.14 persen merupakan desa bertipologi pertanian.Dengan demikian, pembangunan sektor pertanian dapat beriring dengan pembangunan desa.Peluang tersebut telah mendapat dukungan kebijakan pemerintah secara nasional.Tujuan pembangunan desa yang termaktub dalam UU No. 6 Tahun 2014 tentang Desa adalah meningkatkan kesejahteraan, peningkatan kualitas sumber daya manusia dan penanggulangan kemiskinan masyarakat desa melalui pemanfaatan dan pengelolaan sumberdaya alam dan lingkungan setempat secara berkelanjutan. Dengan demikian, upaya pembangunan sektor pertanian nasional dapat bersinergi dengan upaya pembangunan desa agar lebih efektif dan efisien.

Perencanaan pembanguan desa dan pertanian menghadapi hambatan berupa permasalahan yang kompleks.Hakim et al. (2014) menemukan bahwa kondisi sosial ekonomi yang rendah memberikan sumbangsih terhadap menurunnya kualitas lahan pertanian.Hal tersebut menandakan bahwa pembangunan pertanian dan desa tidak dapat dipandang secara parsial, harus menyeluruh.Perencanaan pembangunan desa dan pertanian semestinya dapat memastikan bahwa kegiatan pembangunan saat ini tidak mewariskan keadaan yang buruk bagi generasi mendatang.Menurut Lawrence (1997) dalam IAMO (2007), penilaian pembangunan berkelanjutan menerapkan prinsip-prinsip keberlanjutan untuk memastikan apakah, dan sejauh mana tindakantindakan dapat memungkinkan keberlanjutan suatu wilayah.Pembangunan wilayah di pedesaan maupun perkotaan, seharusnya tidak hanya bertumpu pada pencapaian pertumbuhan ekonomi saja, tetapi juga harus berdasarkan pada nilai-nilai pembangunan berkelanjutan di segala aspek (Hall dan Ulrich, 2000).

Perencanaan pembangunan yang dilakukan pemerintah desa harus dapat menyelesaikan kompleksitas permasalahan yang ada.Perencanaan yang tepat setidaknya dapat mengurangi masalah baru yang dapat ditimbulkan oleh pembangunan yang dilakukan. Oleh karena itu, perencanaan pembangunan desa membutuhkan sebuah inovasi dan sumber pengetahuan yang akurat bagi masyarakat mengenai ruang yang akan dibangunnya. Jalinan konstruksi pengetahuan dan level inovasi tersebut memiliki sumbangsih besar dalam perencanaan, pembangunan, pemanfaatan dan pengelolaan potensi sumberdaya yang tersedia di desa secara tepat (Salman, 2012). Informasi tersebut dapat diperoleh melalui data spasial desa.Data spasial dapat memberikan informasi akurat tentang kondisi lahan terbaru (land existing) sehingga masyarakat desa dapat merencanakan bagaimana memanfaatkan ruang desa dalam jangka panjang.

Teknologi pemetaan dengan menggunakan Unmanned Aerial Vehicle (UAV) atau tanpa awak yang populer dengan sebutan drone dapat menjadi pilihan alternatif. Inovasi tersebut dapat disandingkan dengan inovasi lainnya dalam bidang pemetaan seperti pemetaan berbasis satelit, pemotretan udara skala besar lainnya.Pemanfaatan dan pengembangan teknologi pemetaan menggunakan drone sangat potensial dan sesuai dengan karakter topografis dan geografis Indonesia (Wikantika, 2009).Penggunaan teknologidronedalam pembuatan peta membutuhkan biayay yang relatif rendah, waktu relatif cepat, dan aman dalam berbagai kondisi cuaca (Shofiyanti 2011).

Hasil penelitian Sjaf (2015) mengungkapkan bahwa pemanfaatan drone dapat memudahkan masyarakat desa dalam menyusun perencanaan yang matang dengan adanya basis data yang kuat dari inovasi drone.Penggunaan drone sangat efektif digunakan dalam penelusuran informasi spasial yang akurat, yang selanjutnya dapat memudahkan penataan desa seperti batas desa berbasis koordinat, dan perencanaan pembangunan secara partisipatif. Data citra dari drone, juga dapat memberikan informasi mengenai dampak dari kejadian luar biasa di desa seperti sedimentasi, kerusakan vegetasi, serta sebaran dan jumlah aset yang dimiliki desa.

Dengan demikian, data spasial yang diperoleh dari drone dapat dimanfaatkan dalam membangun sarana dan prasarana yang dapat menunjang pertumbuhan ekonomi dan kesejahteraan masyarakat desa.Tujuan dari penelitian ini adalah:

1. Menganalisis penggunaan lahan aktual berbasis citra drone di wilayah penelitian. 
2. Menganalisis daya dukung lahan pertanian di wilayah penelitian.

3. Menyusun arahan perencanaan pembangunan pertanian berkelanjutan di wilayah penelitian.

\section{Metode Penelitian}

\subsection{Tempat dan Waktu Penelitian}

Fokus studi penelitian ini dilaksanakan di Desa Sukadamai, Kecamatan Dramaga, Kabupaten Bogor, Provinsi Jawa Barat.Selain itu, pengumpulan data persepsi pakar dilakukan di Kecamatan Dramaga, Kabupaten Bogor, Provinsi Jawa Barat.Penelitian ini dilaksanakan pada bulan Juni tahun 2017 sampai bulan November tahun 2018.

\subsection{Metode Pengumpulan Data}

Data penelitian ini berupa data primer dan data sekunder.Peneliti menggunakan data primer berupa peta citra drone, data existing penggunaan lahan desa, serta jenis komoditi yang dikembangkan oleh masyarakat desa. Data sekunder yang digunakan berupa data potensi desa dan data sosial ekonomi masyarakat desa yang bersumber dari Badan Pusat Statistik (BPS) dan Dokumen Profil Desa Sukadamai.

Penelitian dilaksanakan dengan tiga tahap kegiatan yaitu: 1) pengumpulan data meliputi: pembuatan peta desa secara partisipatif dengan memanfaatkan inovasi citra drone, identifikasi daya dukung lahan pertanian, dan identifikasi komoditi unggulan; 2) perumusan hirarki dan strategi pembangunan desa pertanian berkelanjutan; dan 3) menyusun arahan strategi pembangunan desa pertanian berkelanjutan.

\subsection{Prosedur Analisis Data}

\subsubsection{Analisis penggunaan lahan aktual}

Penelitian ini menggunakan interpretasi citra drone sebagai bahan untuk mengklasifikasikan penggunaan lahan di Desa Sukadamai, Kecamatan Dramaga, Kabupaten Bogor. Proses Klasifikasi penggunaan lahan akan melalui tiga tahapan yaitu: (1) pemotongan batas area desa objek penelitian; (2) digitasi citra drone secara partisipatif; dan (3) klasifikasi penggunaan lahan. Proses interpretasi citra dengan klasifikasi terbimbing, diikuti dengan pengecekan lapang.

\subsubsection{Analisis daya dukung lahan pertanian}

Penilaian daya dukung lahan pertanian dilakukan dengan mengukur perbandingan ketersediaan dan kebutuhan lahan pertanian. Pengukuran tersebut mengacu pada Peraturan Menteri Lingkungan Hidup (Permen LH) No. 17 tahun 2009 tentang pedoman penentuan daya dukung lingkungan hidup dalam penataan ruang wilayah.Nilai ketersediaan lahan yang dinilai berdasarkan jumlah kemampuan produksi aktual seluruh komoditas dalam wilayah terukur. Nilai kebutuhan lahan diukur dari jumlah populasi penduduk dan kebutuhan lahan per orang setara dengan kemampuan lahan dalam menghasilkan 1 ton beras per tahun yang diasumsikan sebagai kebutuhan hidup layak (KHL).Untuk memudahkan analisis, digunakan faktor konversi berupa harga komoditas.Fahmuddin (2016) menjelaskan bahwa asumsi nilai kebutuhan hidup layak sebesar setara 1 ton beras dalam Permen LH No. 17 tahun 2009 tersebut dapat dianggap sama dengan komponen nilai hidup layak yang diatur oleh keputusan menteri tenaga kerja mengenai nilai upah minimum regional (UMR) atau upah minimum kabupaten/kota (UMK) yang berlaku di masing-masing wilayah.

Penghitungan nilai daya dukung lahan dilakukan dengan tahapan sebagai berikut (Permen LH No. 19 Tahun 2009):

1. Rumus perhitungan ketersediaan (Supply) lahan:

$S_{L}=\frac{\sum(P i \times H i)}{H b} \times \frac{1}{P t v_{b}}$

Keterangan:

$\mathrm{SL}=$ Ketersediaan Lahan (ha)

$\mathrm{Pi}=$ Produksi aktual tiap jenis komoditi (satuan tergantung kepada jenis komoditas)

$\mathrm{Hi}=$ Harga satuan tiap jenis komoditas (Rp/satuan) di tingkat produsen/petani

$\mathrm{Hb}=$ Harga satuan beras $(\mathrm{Rp} / \mathrm{kg}) \mathrm{di}$ tingkat produsen/petani.

Ptvb $=$ Produktivitas beras $(\mathrm{kg} / \mathrm{ha})$

Nilai produksi komoditi selain beras akan sisetarakan dengan faktor konversi berupa harga beras setempat.

2. Rumus penghitungan kebutuhan (demand) lahan:

$D_{L}=N \times K H L_{L}$

Keterangan:

DL = Total kebutuhan lahan setara beras (ha)

$\mathrm{N} \quad=$ Jumalah penduduk (orang)

KHLL = Luas lahan yang dibutuhkan untuk kebutuhan hidup layak per penduduk:

a. Luas lahan yang dibutuhkan untuk kebutuhan hidup layak per penduduk merupakan kebutuhan hidup layak per penduduk dibagi produktifitas beras lokal.

b. Kebutuhan hidup layak per penduduk diasumsikan sebesar 1 ton setara beras/kapita/tahun.

c. Daerah yang tidak memiliki data produktivitas beras lokal, dapat menggunaan data rata-rata produktivitas beras nasional sebesar $2400 \mathrm{~kg} / \mathrm{ha} /$ tahun.

3. Penilaian status daya dukung lahan

Nilai daya dukung lahan diperoleh dari kedua nilai tersebut di atas.Bila nilai ketersediaan lahan (SL) lebih besar dari kebutuhan lahan (DL) berarti daya dukung lahan dinyatakan surplus.Sedangkan bila nilai SL lebih kecil daripada nilai DL maka daya dukung lahan dinyatakan defisit atau terlampaui.

\subsubsection{Penyusunan arahan strategi pembangunan desa pertanian berkelanjutan}

Peneliti merumuskan permasalahan dan faktor penunjang dalam mewujudkan desa pertanian berkelanjutan di Desa Sukadamai, Kecamatan Dramaga, Kabupaten Bogor. Proses perumusan tersebut melalui proses identifikasi masalah melalui proses focus group discussion (FGD) dengan beberapa petani setempat sebagai stakeholder pertanian di wilayah penelitian. Dalam proses FGD, 
peneliti mengungkapkan temuan-temuan sebelumnya dan mengarahkan para peserta diskusi untuk mengungkapkan faktor-faktor yang perlu diperhatikan serta alternatif kegiatan yang dapat dilakukan dalam mewujudkan pertanian berkelanjutan.

Dalam rangka penentuan alternatif prioritas dalam menyusun arahan pembangunan desa pertanian berkelanjutan, penelitian ini menggunakan Analytical Hierarchy Process (AHP).Metode AHP merupakan metode pengambilan keputusan multikriteria yang ditemukan dan dikembangkan oleh Saaty (1993) dengan menggunakan pendekatan hierarki fungsional yang berdasarkan pada persepsi manusia.Metode AHP adalah salah satu metode yang paling banyak digunakan pada penelitian untuk pengambilan keputusan Multiple Criteria Decision Making (MCDM) atau multikriteria.Peningkatan trend tersebut didukung oleh kemampuan klarifikasi mengenai karakterisasi kriteria dan indikator dalam pengukuran multikriteria (Diaz-Balteiro et al. 2017).

Penyusunan arahan pembangunan desa pertanian berkelanjutan melalui tahapan sesuai dengan kaidah pengoperasian AHP.Formulasi kriteria hingga alternatif menyesuaikan dengan permasalahan yang teridentifikasi di lapangan. Langkah-langkah AHP dalam penelitian ini adalah sebagai berikut:
2. Wawancara pakar menggunakan kuisioner, menilai pengaruh masing-masing faktor terhadap faktor lainnya denganmatriksperbandingan berpasangan (pairwise comparison). Nilai pada matriks perbandingan berpasanganmenggunakan skala yang dapat mengambarkan besarnya kepentingan suatu variabel dibanding variabel yang lain.

3. Pakar yang dimaksud pada poin 2 terdiri dari:

a)Akademisi: pakar ekologi pertanian, ekonomi pertanian, dan sosiologi pedesaan (3 orang);

b)Praktisi: mereka yang memiliki pengalaman dan pengetahuan mumpuni dalam perencanaan pembangunan pertanian dan pedesaan (4 orang). c) Pemerintah Desa Sukadamai (2 orang)

4. Pengolahan data, data penilaian dari masingmasing pakar diolah menggunakan software expert choice V.11. Nilai dapat diterima jika nilai inkonsistensinya lebih kecil dari 0.1. Jika lebih besar dari 0.1 maka perlu dilakukan pengecekan kembali baik terhadap nilai input maupun kepada responden pakar; dan

5. Menyusun implementasi manajerial strategi berdasarkan nilai prioritas alternatif.

\section{Hasil dan Pembahasan}

\subsection{Penggunaan Lahan Aktual}

Penampakan citra desa merupakan langkah untuk memahami kondisi penggunaan lahan aktual

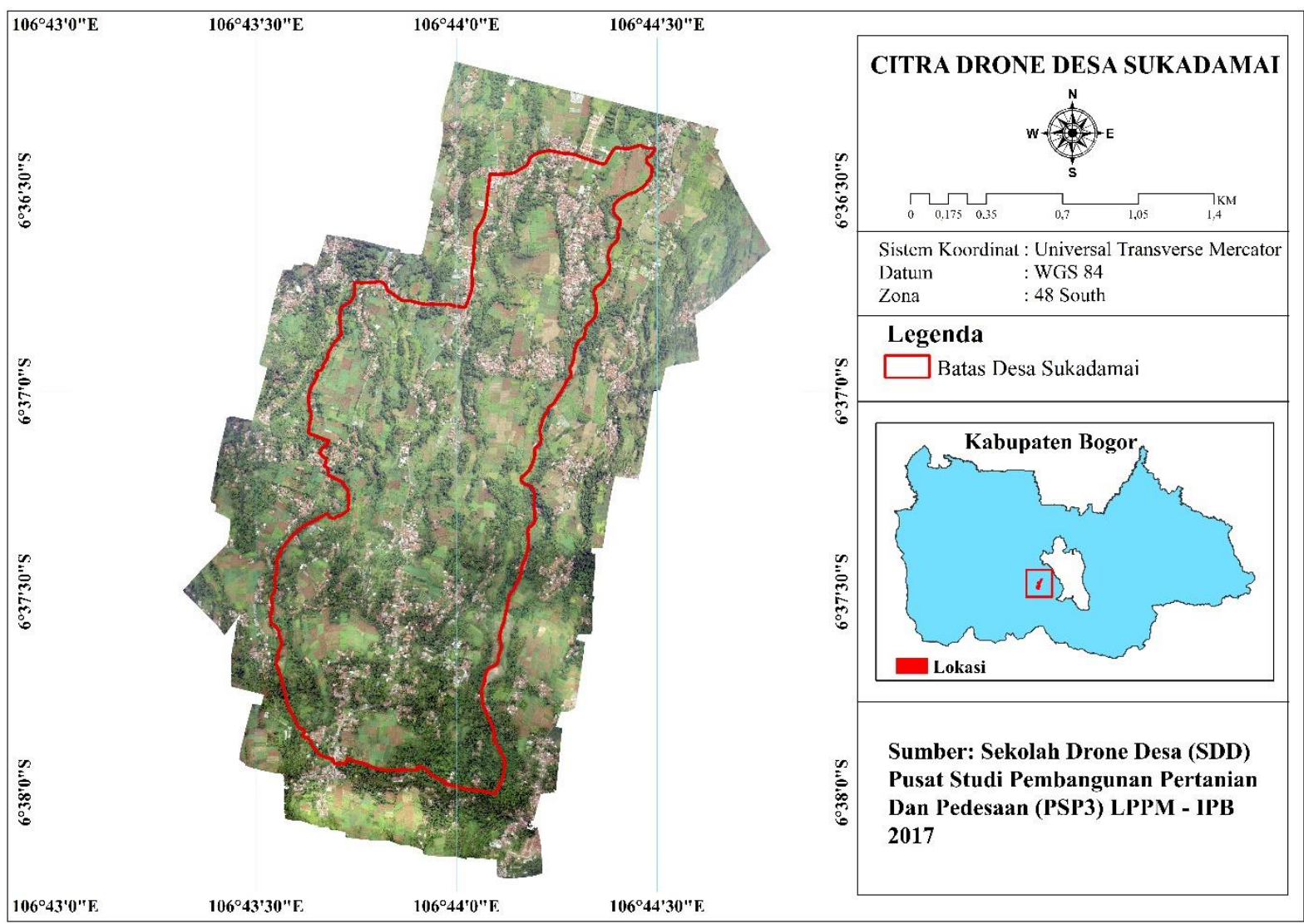

Gambar 1Citra Drone Desa Sukadamai Kabupaten Bogor, Direkam 14 Juni 2017

1. Penyusunan hirarki, struktur hirarki disusun dari sasaran atau goal, aktor, kriteria dan alternatif strategi berdasarkan pada permasalahan yang dihadapi. di Desa Sukadamai, Kabupaten Bogor. Peneliti menggunakan data citra desa yang bersumber dari hasil penangkapan gambar menggunakan droneberupa Unmanned Aerial Vehicle (UAV)/drone 
jenisfixed wing. Proses penangkapan citra denganmenggunakan drone terlaksana pada tanggal 14 Juni 2017. Hasil citra dari drone dipotong di sekitar perbatasan desa(lihat Gambar 1).Citra foto udara udara tersebut merupakan dasar rujukan utama dalam penelitian ini untuk dianalisis dan menghasilkan peta orthophoto desa, peta tematik desa, dan informasi spasial lainnya.

Citra desa dari pesawat drone digunakan sebagai bahan acuan untuk memperoleh klasifikasi penggunaan lahan di Desa Sukadamai. Proses interpretasi citra drone memerlukan kecermatan dan pemahaman intrepeter mengenai lokasi penelitian. Munibah (2008) menjelaskan bahwa proses interpretasi citra dilakukan dengan berdasar pada visualisasi warna/rona, bentuk, tekstur, pola, ukuran, bayanangan, dan pengetahuan interpreter yang dikuatkan oleh hasil verifikasi lapang. Oleh karena itu, peneliti melakukan interpretasi citra drone secara partisipatif bersama tokoh masyarakat dan Pemerintah Desa sebagai informan yang mengetahui penggunaan lahan di Desa Sukadamai.Interpretaer yang dipilih adalah ketua rukun warga (RW), ketua rukun tetangga (RT), dan Sekretaris Desa Sukadamai.

Proses klasifikasi penggunaan lahan dilakukan dengan kebutuhan analisis penggunaan lahan aktual.Hasil klasifikasi penggunaan lahan terbagi menjadi dua kriteria utama yaitu daerah bervegetasi dan non-vegetasi. Secara menyeluruh, klasifikasi penggunaan lahan Desa Sukadamai terdiri dari: permukiman dan bangunan lainnya; daerah pertanian; kebun campuran; peternakan; kolam perikanan; sungai; jalan kabupaten; jalan lokal; jembatan; saluran irigasi; tanah kosong; dan pemakaman. Berdasarkan interpretasi citra drone maka secara spasial sebaran penggunaan lahan aktualdi Desa Sukadamai sebagaimana terlihat pada Gambar 2.

Tabel 1Penggunaan lahan Desa Sukadamai

\begin{tabular}{clrr}
\hline No. & \multicolumn{1}{c}{ Penggunaan Lahan } & Luas (ha) & \multicolumn{1}{c}{ \% } \\
\hline 1 & Permukiman dan Bangunan & 51.461 & 19.452 \\
& Lainnya & 112.942 & 42.693 \\
2 & Daerah Pertanian & 88.881 & 33.598 \\
3 & Kebun Campuran & 0.668 & 0.252 \\
4 & Peternakan & 1.764 & 0.667 \\
5 & Kolam Perikanan & 2.274 & 0.859 \\
6 & Sungai & 1.939 & 0.733 \\
7 & Jalan Kabupaten & 2.713 & 1.026 \\
8 & Jalan Lokal & 0.013 & 0.005 \\
9 & Jembatan & 0.391 & 0.148 \\
10 & Saluran Irigasi & 0.867 & 0.328 \\
11 & Tanah Kosong & 0.635 & 0.240 \\
12 & Pemakaman & $\mathbf{2 6 4 . 5 4 7}$ & 100.000 \\
\hline Jumlah & &
\end{tabular}

Hasil interpretasi citra drone Desa Sukadamai tahun 2017 pada Tabel 1mengungkapkan bahwa penggunaan lahan sebagai daerah pertanian adalah yang terbesar dengan luas mencapai 112.942 ha
(42.693 persen). Hal tersebut menggambarkan bahwa Desa Sukadamai merupakan desa bertipologi desa pertanian, sebagaimana sebagian besar tipologi desa di Indonesia. Penggunaan lahan terluas kedua adalah kebun campuran seluas 88.881 ha (33.598 persen).Sedangkan penggunaan lahan terluas ketiga, keempat dan kelima adalah permukiman dan bangunan lainnya, jalan lokal dan sungai atau badan air dengan masing-masing luasan 51.461 ha $(19.452$ persen), 2.713 ha (1.026 persen) dan 2.274 ha $(0.859$ persen).

Potensi pertanian di Desa Sukadamai dapat terlihat dari proporsi penggunaan lahan untuk daerah pertanian yang cukup besar.Berdasarkan observasi lapang yang dilakukan, penggunaan lahan untuk daerah pertanian memang sangat mudah ditemukan di berbagai wilayah di Desa Sukadamai.Kondisi eksisting penggunaan lahan tersebut memberikan gambaran bahwa sektor pertanian merupakan hal yang sangat potensial untuk dikembangkan di Desa Sukadamai.Penggunaan lahan lainnya sebagai sektor penopang yaitu aliran air berupa sungai dan saluran irigasi, serta akses jalur transportasi sangat menunjang upaya pengembangan komoditi pertanian. Kondisi tersebut akan lebih baik jika didukung oleh kualitas lahan yang baik dan iklim mikro yang sesuai dengan komoditi yang tengah dikembangkan oleh masyarakat tani di Desa Sukadamai. Secara umum kondisi iklim mikro di Desa Sukadamai sama dengan iklim Kecamatan Dramaga, Kabupaten Bogor, Provinsi Jawa barat. Catatan Stasiun Meteorologi Darmaga dalam BPS (2018), pada tahun 2017 terjadi 255 hari hujan atau rata-rata 21 hari hujan setiap bulannya. Curah hujan Kecamatan Dramaga sepanjang tahun 2017 mencapai $3936 \mathrm{~mm}$. Suhu udara rata-rata berkisar antara $24.4^{\circ} \mathrm{C}$ sampai $29.4^{\circ} \mathrm{C}$.

Tantangan ke depan adalah keterbatasan ruang yang tersedia di Desa Sukadamai untuk menanggung pertumbuhan penduduk. Nilai pertumbuhan penduduk Desa Sukadamai rata-rata mencapai 2.19 persen setiap tahun (Pemdes Sukadamai, 2017).Pertumbuhan penduduk akan beriringan dengan meningkatnya kebutuhan penggunaan lahan sebagai sarana pemukiman dan menggerus penggunaan lahan yang tidak terbangun seperti daerah pertanian atau perkebunan campuran. Pertumbuhan penduduk yang semakin padat akan memicu timbulnnya permasalahan lingkungan hingga permasalahan sosial dan ekonomi masyarakat di dalam wilayah tersebut. Hasil penelitian Harlik et al. (2013) menemukan bahwa kepadatan penduduk berpengaruh positif dan signifikan pada tingkat kemiskinan. Hal tersebut dipicu oleh beratnya beban penduduk pada lahan yang biasanya diikuti oleh peningkatan kebutuhan barang konsumsi. Kenyataan tersebut dapat saja terjadi di daerah lain, bahkan pada tingkat wilayah desa. 


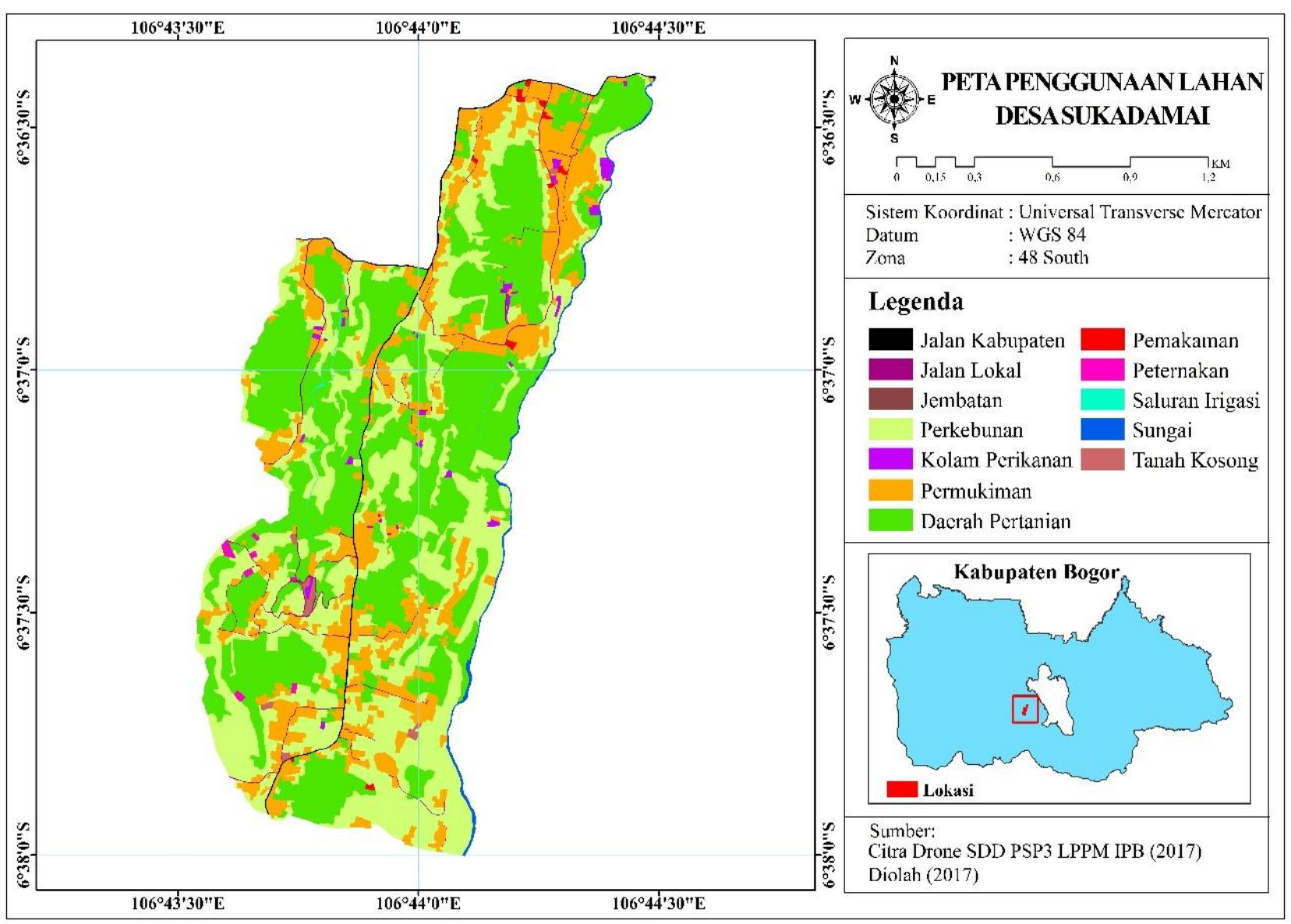

Gambar 2 Peta Penggunaan lahan Desa Sukadamai

Analisis penggunaan lahan selanjutnya mengurai penggunaan lahan daerah pertanian pada level komoditi.Informasi tersebut berasal dari dijitasi partisipatif bersama informan.Penelusuran mendalam ini untuk mengetahui komoditi pertanian yang dikembangkan oleh petani di Desa Sukadamai serta untuk memudahkan analisis selanjutnya terkait daya dukung lahan pertanian.Interpretasi citra dronepada Gambar 3menunjukkan sebaran komoditi di Desa Sukadamai.

Jenis komoditi yang dikembangkan oleh masyarakat Desa Sukadamai berdasarkan interpretasi citra drone. Hasil interpretasi citra drone pada lahan daerah pertanian menunjukkan komoditi yang dikembangkan adalah pisang, jagung, ubi kayu, ubi jalar, padi sawah, dan talas.Sedangkan pada lahan kebun campuran, komoditi sulit untuk diidentifikasi karena rapatnya kanopi pohon dari komoditi yang dikembangkan secara bercampur. Oleh karena itu, jenis komoditi padalahan perkebunan campuran dilakukan observasi dan verisifikasi lapang sehingga ditemukan beberapa komoditi diantaranya adalah pala, durian, serta pepohonan lain yang dibiarkan tumbuh tanpa perawatan khusus.

Komoditi tersebut tersebar hampir secara merata di seluruh wilayah desa.Setiap komoditi yang dikembangkan dengan porsi luas lahan yang berbeda.Luas sebaran lahan pengembangan setiap komoditi di lahan daerah pertaniantersaji pada Tabel 2.Data padaTabel 2 menunjukkan bahwa petani di Desa Sukadamai dominan mengembangkan komoditi ubi jalar (91.150 ha).Kemudian secara berturut-turut diikuti oleh komoditi ubi kayu, jagung, talas, padi sawah dan pisang.

Tabel 2.Luas sebaran komoditi pertanian dan jumlah panen di Desa Sukadamai

\begin{tabular}{lcc}
\hline Jenis komoditi & Luas tanam (ha) & $\begin{array}{c}\text { Frekuensi panen per } \\
\text { tahun }\end{array}$ \\
\hline Pisang & 0.780 & 2 \\
Jagung & 3.014 & 3 \\
Ubi kayu & 14.274 & 2 \\
Ubi jalar & 91.150 & 3 \\
Padi sawah & 1.538 & 2 \\
Talas & 2.186 & 1 \\
\hline
\end{tabular}

Sumber: Data penelitian (2018)

Status daya dukung lahan pertanian pada penelitian ini merupakan hasil perbandingan antara ketersediaan $\left(\mathrm{S}_{\mathrm{L}}\right)$ dan kebutuhan $\left(\mathrm{D}_{\mathrm{L}}\right)$ lahan pertanian.Analisis daya dukung lahan yang dilakukan mengacu pada produktifitas setiap komoditas yang berhasil dirangkum oleh peneliti.Pada tahap pertama, peneliti menganalisis ketersediaan lahan $\left(\mathrm{S}_{\mathrm{L}}\right)$ dengan mengonversi nilai produktifitas setiap komoditi menjadi nilai produksi beras. Hal ini sesuai arahan Permen LH No. 19 Tahun 2009 yang menyebutkan bahwa ketersediaan lahan ditentukan berdasarkan data total produksi aktual setempat dari masing-masing komoditas di suatu wilayah, dengan menjumlahkan nilai produksi dari semua komoditas yang ada di wilayah tersebut. Untuk penjumlahan ini digunakan harga sebagai faktor konversi karena setiap komoditas memiliki satuan yang 
beragam.Faktor konversi yang digunakan untuk menyetarakan produk non beras dengan beras adalah harga.

1. Penghitungan Ketersediaan (Supply) Lahan
Untuk mengetahui ketersediaan lahan pangan Desa Sukadamai:

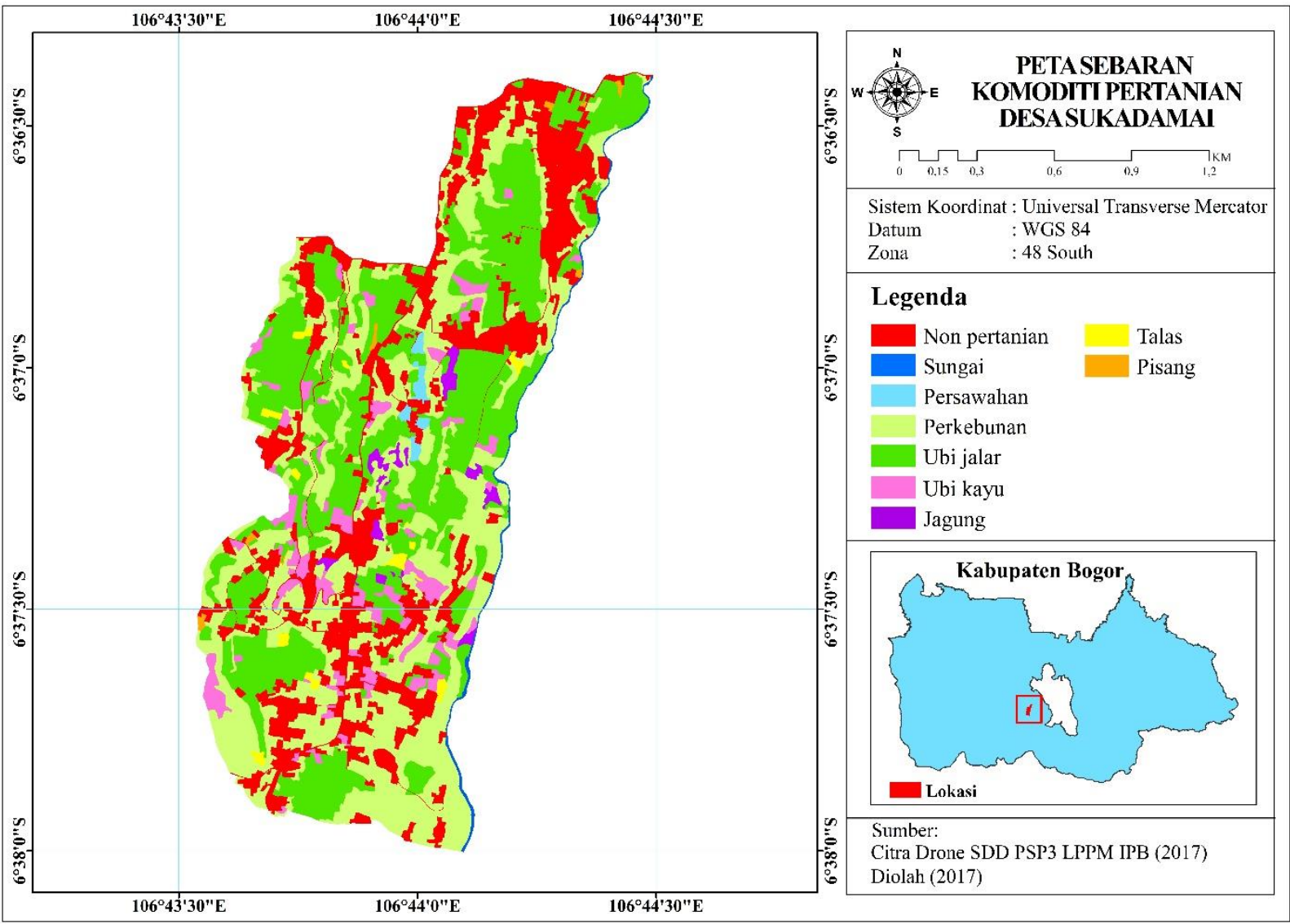

Gambar 3.Peta sebaran komoditi di Desa Sukadamai

Tabel 3.Penghitungan ketersediaan (Supply) lahan Desa Sukadamai

\begin{tabular}{|c|c|c|c|c|c|}
\hline No. & Komoditas & Satuan & Produksi (Pi) & Harga satuan (Hi) & Nilai produksi (Pi x Hi) \\
\hline 1 & Pisang & $\mathrm{Kg}$ & 1560 & 27000 & 42114276 \\
\hline 2 & Jagung & $\mathrm{Kg}$ & 108517 & 2500 & 271293300 \\
\hline 3 & Ubi kayu & $\mathrm{Kg}$ & 428232 & 1500 & 642348000 \\
\hline 4 & Ubi jalar & $\mathrm{Kg}$ & 3828305 & 3000 & 11484916380 \\
\hline 5 & Padi Sawah & $\mathrm{Kg}$ & 19992 & 4100 & 81965806 \\
\hline 6 & Talas & $\mathrm{Kg}$ & 13114 & 4000 & 52457280 \\
\hline 7 & Durian & Buah & 738 & 25000 & 18450000 \\
\hline 8 & Pala & $\mathrm{Kg}$ & 2500 & 25000 & 62500000 \\
\hline 10 & Perikanan & $\mathrm{Kg}$ & 6174 & 35000 & 216090000 \\
\hline 11 & Domba & Ekor & 879 & 2000000 & 1758000000 \\
\hline 12 & Kambing & Ekor & 301 & 1500000 & 451500000 \\
\hline 13 & Ayam kampung & Ekor & 2090 & 70000 & 146300000 \\
\hline 14 & Kerbau & Ekor & 6 & 17000000 & 90000000 \\
\hline \multirow[t]{2}{*}{15} & Itik & Ekor & 65 & 60000 & 3900000 \\
\hline & TOTAL & & & & 15321835042 \\
\hline
\end{tabular}

Sumber: Data diolah (2018)

$$
\begin{aligned}
S_{L} & =\frac{\sum(P i \times H i)}{H b} \times \frac{1}{P t v_{b}} \\
& =\frac{15321835042}{8500} \times \frac{1}{6760} \\
& =266.652 \mathrm{ha}
\end{aligned}
$$

Dengan demikian, analisis yang dilakukan menunjukkan bahwa ketersediaan lahan setara beras $\left(\mathrm{S}_{\mathrm{L}}\right)$ di Desa Sukadamai adalah seluas 266.652 ha.

2. Penghitungan kebutuhan (demand) lahan:
Besarnya nilai kebutuhan lahan diukur dengan mengakumulasikan kebutuhan hidup layak setiap penduduk.Standar kebutuhan hidup layak disetarakan dengan kemampuan lahan di wilayah setempat memproduksi beras 1 ton per tahun.Produktifitas padi sawah (gabah kering panen) di Desa Sukadamai mencapai 13000 kg/tahun dengan nilai rendemen sebesar 52 persen.Dengan demikian, produktifitas beras di Desa Sukadamai sebesar $6760 \mathrm{~kg} / \mathrm{ha} /$ tahun. Luas kebutuhan lahan yang layak bagi setiap penduduk setara dengan 
kemampuan lahan setempat dalam memproduksi 1ton beras per tahun yakni seluas seluas 0.148 ha.Secara detail, perhitungan untuk mengetahui luas lahan pangan yang dibutuhkan penduduk Desa Sukadamai untuk hidup layak $\left(\mathrm{D}_{\mathrm{L}}\right)$, adalah:

$$
\begin{aligned}
D_{L} & =N \times K H L_{L} \\
& =8305 \times \frac{1 \text { ton }}{P t v_{b}} \\
& =8305 \times 0.148 \mathrm{ha} \\
= & 1228.550 \mathrm{ha}
\end{aligned}
$$

Hasil analisis kebutuhan lahan $\left(D_{L}\right)$ untuk 8305 jiwa penduduk Desa Sukadamai adalah seluas 1285.059 ha.Nilai tersebut sangat jauh jika dibandingkan dengan luas lahan Desa Sukadamai sebesar 264.547 ha. Dari data tersebut dapat pula disimpulkan bahwa jumlah penduduk Desa Sukadamai yang dapat didukung oleh lahan pertanian, perikanan, perkebunan dan peternakan adalah 1802.57 jiwa atau 21.70 persen dari jumlah penduduk Desa Sukadamai. Kondisi tersebut menjadi peringatan dalam perencanaan pembangunan yang akan dilakukan ke depan, mengingat bahwa pertumbuhan jumlah penduduk di masa mendatang yang juga beriringan dengan bertambahnya kebutuhan lahan.

\section{Status daya dukung lahan}

Berdasarkan analisis tersebut di atas yang menunjukkan bahwa nilai $S_{\mathrm{L}}$ lebih kecil dari $\mathrm{D}_{\mathrm{L}}$, maka status daya dukung lahan pertanian di Desa Sukadamai disimpulkan dalam keadaan defisit atau terlampaui.Rasio perbandingan antara $S_{L}$ dan $D_{L}$ adalah sebesar 0.22. Hal tersebut menggambarkan bahwa ketersediaan lahan di Desa Sukadamai tidak dapat memenuhi kebutuhan produksi hayati bagi penduduk setempat.Kondisi tersebut menandakan bahwa berdasarkan produktifitas lahan yang tersedia, maka penggunaan lahan di wilayah Desa Sukadamai telah melampaui batas kemampuan daya dukung lahan pertanian.Pada keadaan tersebut, maka pemanfaatan lahan tidak dipakai secara efektif (Moniaga 2011).Oleh karena itu, sudah tidak memungkinkan lagi dilakukan penggunaan lahan untuk pembangunan yang bersifat ekspansif serta eksploratif lahan.

Lahan-lahan yang berada pada status daya dukung lahan yang rendah perlu mendapatkan program peningkatan produktivitas, intensifikasi dan ekstensifikasi melalui perbaikan teknologi atau menekan pertumbuhan penduduk (Purnama 2015). Menurut Meilani (2013), penurunan daya dukung lahan pertanian dapat dipengaruhi oleh jumlah penduduk yang terus meningkat, berkurangnya luas lahan pertanian, jumlah petani, dan jumlah komoditi di wilayah tersebut. Sedangkan menurut Pasandaran (2006), paling tidak ada tiga faktor yang menekan daya dukung lahan pertanian, baik sendiri-sendiri maupun bersama-sama, yaitu kelangkaan sumber daya lahan dan air, dinamika pembangunan, dan peningkatan jumlah penduduk.Selain itu, hasil penelitian Moniaga (2011) menyebutkan bahwa luas panen dan produktifitas pertanian merupakan faktor yang harus diperhatikan untuk meningkatkan daya dukung lahan pertanian.Nilai daya dukung lahan pertanian bersifat relatif, nilainya dapat berubahubah tergantung pada adanya perubahan penggunaan teknologi dan faktor kebudayaan setempat.Penggunaan teknologi akan memengaruhi nilai produktifitas lahan, sementara faktor kebudayaan akan menentukan perilaku dan kebutuhan hidup masing-masing individu.

Terdapat beberapa upaya yang dapat dilakukan dalam mengatasi penurunan nilai daya dukung lahan. Upaya yang diusulkan oleh Hardjasoemantri (1989) dalam Putra et al. (2016) antara lain dengan cara: 1) Konversi lahan, yaitu merubah jenis penggunaan lahan ke arah usaha yang lebih menguntungkan tetapi disesuaikan wilayahnya; 2) intensifikasi lahan, yaitu dalam menggunakan teknologi baru dalam usahatani; dan 3) Konservasi lahan, yaitu usaha untuk mencegah semakin tingginya alih fungsi lahan

\subsection{Arahan Pembangunan Pertanian Berkelanjutan Di Desa Sukadamai}

Hasil analisis pada tahapan penelitian sebelumnya menjadi dasar dalam perumusan menentukan penentuan alternatif kebijakan yang selanjutnya dianalisis menggunakan teknik Analytical Hierarchy Process (AHP). Struktur hirarki proses terdiri dari goal, aktor, kriteria dan alternatif. Hirarki proses dalam peneletian ini merupakan hasil analisis penemuan sebelumnya dalam penelitian ini serta wawancara dengan petani dan pemerintah Desa Sukadamai. Peneliti mereduksi data hasil wawancara tersebut, menyajikan data, dan menyimpulkan data menjadi alternatif program dalam mewujudkan desa pertanian berkelanjutan di Desa Sukadamai. Hasil analisis hirarki proses yang menjadi bahan analisis tersaji pada Gambar 4.

Alternatif prioritas pertama pada analisis menggunakan AHP adalah penerapan inovasi intensifikasi lahan yang efektif dan efisien (0.215). Proses kegiatan dapat dilakukan dengan memprioritaskan kriteria adil secara sosial (0.384). Selanjutnya, aktor yang sangat memberikan pengaruh dalam mewujudkan pembangunan pertanian berkelanjutan di Desa Sukadamai adalah pemerintah (0.431).Meski demikian, unsur hirarki lainnya tidak dapat diabaikan, karena saling terkait serta dapat memberikan pengaruh pada terwujudnya desa pertanian berkelanjutan di Desa Sukadamai Kecamatan Dramaga Kabupaten Bogor.

Berdasarkan pada unsur yang memiliki bobot prioritas pertama tersebut maka dapat dilakukan intensifikasi lahan yang efektif dan efisien.Lahan utama yang dapat menjadi objek program adalah lahan yang digunakan untuk mengembangkan komoditi unggulan berupa ubi jalar dan jagung.Pada dasarnya Intensifikasi pertanian diarahkan pada perbaikan seluruh sistem pertanian salah satunya segi kesuburan tanah.Deptan (2004) menganjurkan intensifikasi lahan dalam meningkatkan produktifitas 
lahan, meningkatkan penghasilan petani, meluaskan kesempatan kerja, efisiensi biaya produksi, dan mempertahankan kelestarian sumber daya alam. Berbagai faktor sangat penting untuk diperhatikan, sebab proses intensifikasi pertanian akan menyebabkan berubahnya beberapa proses dalam tanah (Noordwijk dan Hairiah 2006). Perubahan tersebut banyak disebabkan oleh penggunaan bahan kimia dalam usaha tani sehingga justru dapat menurunkan kualitas lahan.

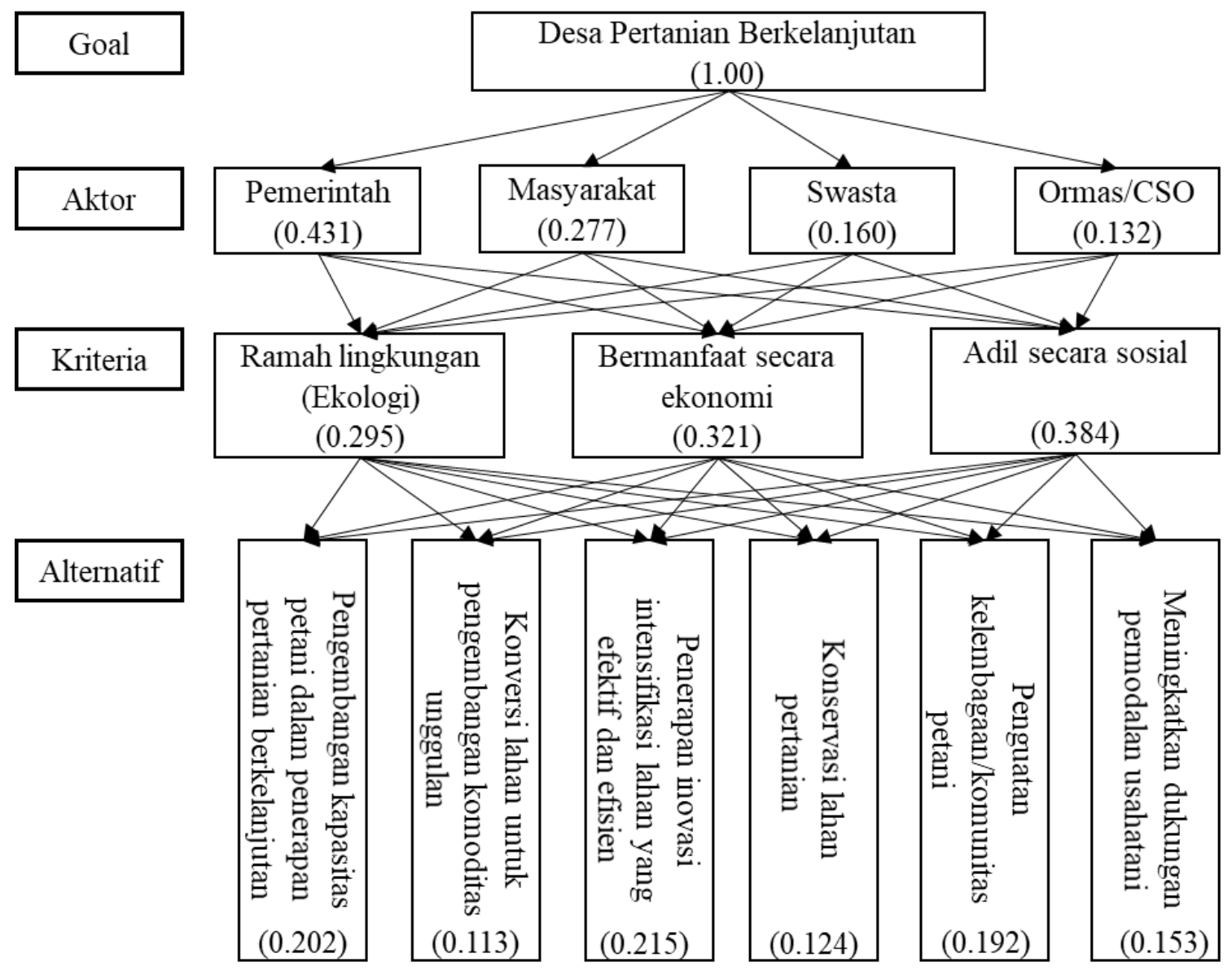

Gambar 4.Hirarki dan bobot prioritas perencanaan pertanian berkelanjutan di Desa Sukadamai

Proses intensifikasi lahan harus dilakukan secara efektif dan efisien. Garnett et al. (2013) memberikan empat dasar pemikiran yang perlu diperhatikan dalam menyelenggarakan intensifikasi berkelanjutan (sustainable intensification) yaitu; 1) kebutuhan untuk meningkatkan produksi; 2) peningkatan produksi harus dipenuhi melalui hasil yang lebih tinggi karena meningkatkan luas lahan di pertanian membutuhkan biaya lingkungan yang besar; 3) ketahanan pangan membutuhkan banyak perhatian untuk meningkatkan kelestarian lingkungan yang selaras dengan peningkatkan produktivitas; dan 4) intensifikasi berkelanjutan merupakan suatu tujuan tetapi tidak menentukan secara apriori bagaimana hal itu harus dicapai atau teknik pertanian yang harus diterapkan, pendekatan yang digunakan harus dengan mempertimbangkan konteks biofisik dan sosial. Hal tersebut sejalan dengan penjelasan Mulyani dan Agus (2017) yang menyatakan bahwa program intensifikasi lahan pertanian sangat perlu untuk ditingkatkan melalui pemanfaatan inovasi teknologi, dan sarana serta prasarana pertanian.Intensifikasi lahan diselenggarakan dengan mengelola lahan pertanian tersedia secara optimal dengan tujuan meningkatka indeks pertanaman kemudian diikuti oleh meningkatnya produktifitas lahan.

Berdasarkan penjelasan tersebut maka secara teknis upaya pembangunan pertanian berkelanjutan di Desa Sukadamai dapat ditempuh dengan melakukan intensifikasi lahan lahan yang efektif dan efisien. Intensifikasi lahan pertanian dapat dimulai dengan menerapkan perbaikan kualitas lahan dengan memberi input eksternal yang minim dan lebih mengedepankan penggunaan input organik yang tersedia di Desa Sukadamai. Bahan organik di Desa Sukadamai cukup tersedia dari aktifitas pertanian dan peternakan.Sampah organik dari sisa hasil panen, limbah peternakan, dan sampah-sampah organik dari kebun campuran dapat dimanfaatkan.Kendala yang dapat saja terjadi adalah sulitnya transformasi kebiasaan petani dalam melakukan intensifikasi pertanian.Untuk itu, program yang bersifat edukatif terhadap petani dapat dilakukan untuk mempercepat peningkatan produksi pertanian dengan memanfaatkan sumberdaya alam yang tersedia secara maksimal. 
Strategi tersebut harus ditunjang dengan memperhatikan kriteria adil secara sosial yang berarti bahwa kebijakan yang dilakukan bersifat merata bagi seluruh masyarakat di Desa Sukadamai.Kebijakan yang diterapkan tidak merugikan atau menguntungkan sebagian masyarakat saja, tetapi memberi manfaat bagi seluruh elemen masyarakat Desa Sukadamai.Oleh karena itu, penguatan kelembagaan/komunitas petani dapat menjadi strategi penunjang sekaligus menjadi media edukasi bagi seluruh petani di Desa Sukadamai.Selain itu,proses intensifikasi lahan pertanian di desa seharusnya ditopang oleh ketersediaan infrastruktur pertanian baik biofisik maupun sosial seperti kelembagaan yang dapat dimanfaatkan seluruh petani.Infrastruktur fisik berupa penunjang sarana produksi seperti saluran irigasi, jalan tani, hingga akses pemasaran hasil pertanian.Pemerintah desa dapat memaksimalkan peran dalam pembangunan infrastruktur tersebut.

Peran pemerintah desa dalam melaksanakan strategi ini sangat besar.Pemerintah melalui kebijakan dan kemampuan pendanaannya dapat memberi dampak besar bagi pembangunan pertanian berkelanjutan di Desa Sukadamai.Pemerintah dapat bekerjasama dengan aktor-aktor lainnya seperti organisasi masyarakat yang telah ada untuk mendampingi kelembagaan atau komunitas petani. Pendampingan tersebut bertujuan untuk meningkatkan kemampuan masyarakat petani dalam mengelola organisasi dan penyelenggaraan strategi pembangunan yang akan dilakukan.

\section{Kesimpulan}

Penggunaan teknologi drone sangat membantu dalam memberikan citra wilayah desa objek penelitian. Penangkapan citra wilayah desa menggunakan drone dapat menjadi alternatif bagi pemerintah desa demi memenuhi kebutuhan informasi spasial desa. Pada penelitian ini, citra drone digunakan menjadi acuan utama pada berbagai Analisa yang dilakukan peneliti. Berdasarkan analisis spasial pada citra drone tersebut, peneliti menemukan bahwa luas wilayah Desa Sukadamai, Kecamatan Dramaga, Kabupaten Bogor adalah 264.547 ha.

Analisis penggunaan lahan aktual di desa Sukadamai Kabupaten Bogor menunjukkan bahwa sektor pertanian memiliki potensi besar untuk berkembang.Hal tersebut merujuk pada luas penggunaan lahan untuk daerah pertanian mencapai 42.693 persen atau seluas 112.942 ha.Selain itu, penggunaan lahan terbesar selanjutnya adalah kebun campuran yang mencapai 33.598persen atau seluas 88.881 ha.Daerah permukiman dan bangunan lainnya seluas 51.461 atau 19.452 persen dari seluruh luas lahan Desa Sukadamai.Selanjutnya penggunaan lahan aktual berturut-turut dari besar ke paling kecil ialah jalan lokal seluas 2.713 ha (1.026persen).Sungai 2.274 ha (0.859), kolam perikanan seluas 1.764 ha $(0.667$ persen $)$, jalan kabupaten seluas 1.939 ha atau 0.733 persen wilayah desa.Kemudian disusul oleh penggunaan lahan sebagai kolam perikanan yang mencapai 1.764 ha (0.667persen), tanah kosong 0.867 ha (0.328persen), peternakan 0.668 ha $(0.252$ persen), pemakaman seluas 0.635 ha $(0.240$ persen), saluran irigasi seluas 0.391 ha (0.148persen) dan terakhir adalah penggunaan lahan untuk jembatan sebesar 0.013 ha atau 0.005 persen dari luas wilayah desa.

Analisis Daya dukung lahan pertanian di Desa Sukadamai menunjukkan bahwa luas lahan pangan tersedia $\left(\mathrm{S}_{\mathrm{L}}\right)$ sebesar 266.652 ha, sedangkan kebutuhan lahan $\left(D_{\mathrm{L}}\right)$ sebesar 1228.550 ha.Hal tersebut berarti bahwa nilai SL lebih kecil dari DL, maka status daya dukung lahan pertanian di Desa Sukadamai dinyatakan defisit atau terlampaui.Rasio perbandingan antara SL dan DL adalah sebesar 0.22.Kemampuan lahan pangan tersedia hanya mampu memenuhi kebutuhan hidup layak (KHL) bagi 1802.57 jiwa atau 21.70 persen dari jumlah penduduk Desa Sukadamai.

Berdasarkan Nilai bobot alternatif pada analisis AHP maka perencanaan pembangunan pertanian berkelanjutan di desa Sukadamai dapat dimulai dengan penerapan inovasi intensifikasi lahan yang efektif dan efisien dengan bobot nilai prioritas sebesar 0.215.Kemudian alternatif selanjutnya adalah Pengembangan kapasitas petani dalam penerapan pertanian berkelanjutan (0.202).Prioritas alternatif ketiga adalah penguatan kelembagaan/komunitas petani (0.192) kemudian Meningkatkan dukungan permodalan usahatani (0.153).Alternatif prioritas kelima adalah konservasi lahan pertanian (0.124) kemudian keenam adalah konversi lahan untuk pengembangan komoditi unggulan (0.113).

\section{DAFTAR PUSTAKA}

Diaz-Balteiro, L., González-Pachón J., Romero C. 2017.Measuring systems sustainability with multicriteria methods: A critical review. European Journal of Operational Research 258(2) 607-616. doi:10.1016/j.ejor.2016.08.075.

[BPS] Badan Pusat Statistik. 2013. Laporan Hasil Sensus Pertanian 2013 (Pencacahan Lanskap). Jakarta.

[Deptan] Departemen pertanian. 2004. Publikasi statistik Pertanian Konsep dan Defenisi. Pusat Data dan Informasi Pertanian.[Internet].[Diunduh 2018 Apr 20];Tersediapada:http://pusdatin.deptan.go.id/statis tik/konsep_defenisi.html.

Fahimuddin MM. 2016.Analisis Daya Dukung Lahan di Kota Baubau, Sulawesi Tenggara [TESIS]. Bogor. Institut Pertanian Bogor.

Garnett, T., Appleby, M.C., Balmford, A., Bateman, I.J., Benton, T.G., Bloomer, P.B., Burlingame, M., Dawkins, L., Dolan, D., Fraser, M. et al. 2013. Sustainable intensification in agriculture: premises and policies. Science341(6141). 33-34 DOI: 10.1126/science.1234485.

Hakim, N.A., Anggraeni, M., Dinanti, D. 2014.Pengaruh Sosial Ekonomi Terhadap Tingkat Kekritisan Lahan Pada Kawasan Budidaya Pertanian (Studi Kasus Desa Ngabab Kecamatan Pujon).[TESIS].Yogyakarta. Universitas Gadjah Mada. 
Harlik, H., Amir, A., Hardiani, H. 2013. Faktor-Faktor yang Mempengaruhi Kemiskinan dan Pengangguran di Kota Jambi.Jurnal Perspektif Pembiayaan dan Pembangunan Daerah, 1(2) Hal 109-120.

[IAMO]Leibniz-Institut für Agrarentwicklung in Mittel- und Osteuropa. 2007. Sustainable rural development: What is the role of the agri-food sector? Die Deutsche Bibliothek [Internet]. [Diunduh 2017 Jan 10]; Tersediapada: http://www.iamo.de/dok/sr_vol39.pdf.

Meliani, D. 2013. Daya dukung lingkungan Kecamatan Rasau Jaya berdasarkan ketersediaan dan kebutuhan lahan. Jurnal Teknik Lingkungan 1(1)Hal1-10.

Moniaga VR. 2011. Analisis daya dukung lahan pertanian. Jurnal Agri-Sosioekonomi 7(2) Hal 61-68.

Mulyani A, Agus F. 2017. Kebutuhan dan Ketersediaan Lahan Cadangan Untuk Mewujudkan Cita-Cita Indonesia Sebagai Lumbung Pangan Dunia Tahun 2045. Analisis Kebijakan Pertanian. 15(1) Hal 1-17. DOI: $10.21082 /$ akp. v15n1.2017.1-17

Noordwijk MV, Hairiah K. 2006. Intensifikasi Pertanian, Biodiversitas Tanah Dan Fungsi Agro-Ekosistem. Jurnal Agrivita28(3) Hal 1- 13.

Pasandaran E. 2006. Alternatif Kebijakan Pengendalian Konversi Lahan Sawah Beririgasi di Indonesia. JLP, 25(4) Hal 123-129

Pranoto A.Y., Aziz M.M., Hasanah N.R., 2013. Rancang Bangun dan Analisis Decision Support System
Menggunakan Metode Analytical Hierarchy Process untuk Penilaian Kinerja Karyawan, J EECCIS 7:(1).

Purnama S. 2015. Analisis Daya Dukung (Carrying Capacity Ratio) Lahan Perkebunan. [Internet] [Diunduh 2017 Jan10];Tersedia pada: http://disbun.jabarprov.go.id/ index.php/artikel/detailartikel/67.

Putra IDGAD, Utama MS, Yasa IGWM. 2016. Analisis Daya Dukung Lahan Berdasarkan Total Nilai Produksi Pertanian Di Kabupaten Gianyar.Jurnal Ekonomi dan Bisnis Universitas Udayana. 5(3) Hal 387-402.

Salman D. 2012.Sosiologi Desa, Revolusi Senyap dan tarian Kompleksitas.Makassar.Ininnawa.

Shofiyanti R. 2011. Teknologi Pesawat Tanpa Awak Untuk Pemetaan Dan Pemantauantanaman Dan Lahan Pertanian. JIP 20 (2) Hal 58 - 64. Jakarta. Kementan

Sjaf S. 2015 Jun 25. Menjawab kekhawatiran dana desa. Kompas. Rubrik Opini: 5 (kol 1-4).

2017. Merebut Masa Depan Pertanian. Kompas. Rubrik Opini, 15 Des 2017: 4 (kol 1-4)

Susilowati S.H. 2016. Fenomena Penuaan Petani Dan Berkurangnya Tenaga Kerja Muda Serta Implikasinya Bagi Kebijakan Pembangunan Pertanian. Jakarta (ID): Forum Penelitian Agro Ekonomi 34(1) Hal 21-34.

Wikantika K. 2009. Unmanned Mapping Technology: Development and Applications. Workshop Sehari "Unmanned Mapping Technology: Development and Applications" (UnMapTech2008). Bandung, Indonesia. 9 Juni 2008. Bandung (ID): ITB 